\title{
Effect of phytosanitary spray solution storage time on the viability of Beauveria bassiana conidia $^{1}$
}

\author{
Renan Zampiroli², Cleyton Batista de Alvarenga ${ }^{2}$, \\ Bruno Sérgio Vieira² ${ }^{2}$ Jair Rocha do Prado ${ }^{3}$, Paula Cristina Natalino Rinaldi², Luiz Fernando Horácio Júnior ${ }^{2}$
}

\section{ABSTRACT}

Adverse weather conditions, or mechanical problems and decrease in the application rate, may increase the storage time of the spray solution in the sprayer tank. This study aimed to assess the effect of the phytosanitary spray solution storage on the germination of Beauveria bassiana conidia, with or without agricultural adjuvants. A completely randomized design was used, in a $13 \times 5$ factorial scheme, consisting of thirteen storage times $(0,4,8,12,16,20,24,28,32,36,40,44$ and $48 \mathrm{~h})$ and five compositions for the spray solution (B. bassiana, B. bassiana + Helper Neutrum, B. bassiana + TA-35, B. bassiana + Nimbus and $B$. bassiana + Orobor). The biological spray solution containing $B$. bassiana conidia and no adjuvants remained viable for use after preparation and the conidial germination decreased 9.2 times after $48 \mathrm{~h}$ when an adjuvant was added.

KEYWORDS: Entomopathogens, fungicide application technology, agricultural adjuvants.

\section{INTRODUCTION}

Brazil is the largest producer and second largest consumer of coffee worldwide (ICO 2018), with an estimated production of 44.97 million $60-\mathrm{kg}$ bags (Arabica and Robusta) in 2018 and a planted area of around 2.2 million hectares. The estimated production in the Minas Gerais state in 2017 was 24.45 million bags, 24.1 million of which were Coffea arabica L. (Conab 2018).

One of the main pests affecting the crop is the coffee berry borer, Hypothenemus hampei (Coleoptera: Curculionidae, Scolytinae). Annual economic losses caused by this insect are estimated

\section{RESUMO}

Efeito do tempo de armazenamento de calda fitossanitária na viabilidade de conídios de Beauveria bassiana

Condições meteorológicas adversas, ou problemas mecânicos e redução na taxa de aplicação, podem aumentar o tempo de armazenamento da calda no tanque do pulverizador. Objetivou-se avaliar o efeito do armazenamento da calda fitossanitária na germinação de conídios de Beauveria bassiana, com e sem adjuvantes. Utilizou-se delineamento experimental inteiramente casualizado, em esquema fatorial $13 \times 5$, composto por treze períodos de armazenamento $(0,4,8,12,16,20,24,28,32$, $36,40,44$ e 48 h) e cinco composições para a calda de pulverização (B. bassiana, B. bassiana + Helper Neutrum, B. bassiana + TA-35, $B$. bassiana + Nimbus e B. bassiana + Orobor). A calda biológica contendo conídios de $B$. bassiana sem adjuvantes manteve-se viável para uso após seu preparo e a germinação dos conídios reduziu-se 9,2 vezes após 48 h com a adição de adjuvante.

PALAVRAS-CHAVE: Entomopatógenos, tecnologia de aplicação de fungicidas, adjuvantes agrícolas.

at USD 287 million in Brazil alone (Oliveira et al. 2012). The most widely used control methods are chemical and biological.

Among the fungi used for its biological control is Beauveria bassiana (Bals.) Vuill., which has been reported attacking the beetle in several countries where it occurs naturally (Neves \& Hirose 2005). As a broadspectrum pathogen, the fungus is capable of colonizing different insect and mite species (Lorencetti et al. 2017, Costa et al. 2018). However, Jenkins \& Grzywacz (2000) reported that fungal and viral biocontrol agents have not yet reached a level of efficacy comparable to that of chemical insecticides or the most widely used bacterial antagonist, Bacillus thuringiensis.

1. Received: Oct. 19, 2018. Accepted: Apr. 22, 2019. Published: Oct. 07, 2019. DOI: 10.1590/1983-40632019v4955513.

2. Universidade Federal de Uberlândia, Instituto de Ciências Agrárias, Monte Carmelo, MG, Brasil.

E-mail/ORCID: renanzampiroli@ufu.br/0000-0002-5082-9111, cleytonalvarenga@ufu.br/0000-0002-0431-6171, brunovieira@ufu.br/0000-0001-8130-8100,paularinaldi@ufu.br/0000-0001-9290-9040, luizfhoracio@hotmail.com/ 0000-0001-8176-7526.

3. Universidade Federal de Uberlândia, Faculdade de Matemática, Monte Carmelo, MG, Brasil. E-mail/ORCID: jairrp@ufu.br/0000-0002-6165-4126. 
In agricultural applications aimed at general pest control, a significant portion of the spray solution may not come into contact with the biological target and the proposed objective is not achieved (Madureira et al. 2015). The advantage of using Beauveria bassiana as an entomopathogen over conventional pesticides is its persistence in the host population under favorable environmental conditions, reducing the population and causing high mortality rates in the larval and adult stages of the target pest (Silva et al. 2006).

In order to improve the performance of the spray application, low concentrations of oil-based adjuvants are recommended, since they can reduce surface tension and rain wash-off and increase the solution spreading, leaf coverage and absorption (Green \& Beestman 2007, Chechetto et al. 2012). Natural adjuvants are based on oils extracted from orange bagasse (Citrus spp.), for example; however, information and studies that provide data on their efficiency in pest and disease management in the field are scarce (Coradini et al. 2016). Despite being less toxic than their conventional counterparts, natural products may affect the biological parameters of entomopathogenic organisms (Potrich et al. 2011). Understanding the interaction between these surfactants and entomopathogenic fungi is vital for increasing the application efficiency without losing the germination characteristics of the fungal spores (Mwamburi et al. 2015).

When weather conditions or mechanical problems halt spraying operations, farmers should be concerned about the effectiveness of the spray solution. Nevertheless, little is known about the viability of stored spray solutions, even at the international level. Given the lack of information available about spray solution degradation, farmers have the following options: 1) discard the solution to prevent costs resulting from ineffective application, which would increase the risk of plant injury (phytotoxicity); 2) apply the solution despite not knowing its control potential. This is exacerbated when a biological product is used due to the behavioral change that occurs in the germination structure of the fungi in suspension over extended periods. Research on the physical, chemical and biological changes in entomopathogens during storage generally focuses on the shelf life of commercial formulations (Marques et al. 2000), as opposed to field conditions.
Under farm storage conditions, a $70 \%$ germination of entomopathogenic fungal conidia is considered satisfactory, whereas Jenkins \& Grzywacz (2000) reported that conidial germination must be $85 \%$ when stored under recommended conditions.

This study aimed to assess the effect of storing a spray solution with and without agricultural adjuvants on the germination of $B$. bassiana conidia.

\section{MATERIAL AND METHODS}

The experiment was conducted during the 2018 growing season at the Universidade Federal de Uberlândia, in Monte Carmelo (18 44'11.02"S, $47^{\circ} 28^{\prime} 59.06^{\prime \prime} \mathrm{W}$ and altitude of $901 \mathrm{~m}$ ), Minas Gerais state, Brazil.

A completely randomized design was used, in a $13 \times 5$ factorial scheme, consisting of thirteen storage times $(0,4,8,12,16,20,24,28,32,36,40,44$ and $48 \mathrm{~h}$ ) and five compositions for the spray solution (Beauveria bassiana, B. bassiana + Helper Neutrum, B. bassiana + TA-35, B. bassiana + Nimbus and $B$. bassiana + Orobor).

The BeauveControl commercial insecticide, produced and sold by Simbiose Agro, containing $40 \mathrm{~g} \mathrm{~kg}^{-1}$ of Beauveria bassiana isolate IBCB 66 $\left(2 \times 10^{9} \mathrm{CFU}\right)$, was used. The fungus was used in aqueous suspension and the spray solution prepared according to the manufacturer's recommendations for controlling coffee berry borer, at a dose of $0.5 \mathrm{~kg} \mathrm{ha}^{-1}$ added with the adjuvants Nimbus, Orobor N1, TA-35 and Helper Neutrum at doses of $5 \mathrm{~mL}^{-1}, 0.75 \mathrm{~mL}^{-1}$, $0.5 \mathrm{~mL}^{-1}$ and $0.5 \mathrm{~mL}^{-1}$, respectively.

The water used to prepare the spray solution was collected from an artesian well $(\mathrm{pH}=5.5)$ used to supply sprayers. In the laboratory, $100 \mathrm{~mL}$ were placed in $125 \mathrm{~mL}$ Erlenmeyer flasks and autoclaved for $30 \mathrm{~min}$, at $120^{\circ} \mathrm{C}$, for sterilization purposes. Next, the sterilized water was added with the spray solution containing $B$. bassiana conidia and adjuvants. The Erlenmeyer flasks containing the respective solutions were kept at ambient temperature and relative humidity until plating.

Conidial germination was assessed in Petri dishes ( $60 \mathrm{~mm}$ x $15 \mathrm{~mm}$ ) containing Potato-DextroseAgar (PDA) medium (39 $\left.\mathrm{g} \mathrm{L}^{-1}\right)$. The medium was diluted in distilled water in a 0.5 L Erlenmeyer flask. After total dilution, the solution was autoclaved under the same conditions previously described. The antibiotic streptomycin sulfate $\left(100 \mathrm{mg} \mathrm{L}^{-1}\right)$ was added 
to the unsolidified medium to prevent the growth of contaminating bacteria. After agitation, the culture medium was poured into the Petri dishes, in line with a methodology adapted from Mertz et al. (2010).

Following the preparation of the spray solution, $0.5 \mathrm{~mL}$ samples were inoculated onto the surface of the growth medium in the center of the Petri dish with a micropipette, spreading the solution across the entire surface of the medium using a Drigalski spatula.

This was performed in a sterile environment, inside a laminar flow cabinet sterilized with $70 \%$ alcohol and ultraviolet (UV) light for $30 \mathrm{~min}$ before plating. The dishes were then sealed with Parafilm ${ }^{\circledR}$ tape and placed in a BOD incubator sterilized with $70 \%$ alcohol for $24 \mathrm{~h}$, at $25 \pm 1{ }^{\circ} \mathrm{C}, 70 \pm 10 \%$ relative humidity and 12-h photoperiod (Silva \& Neves 2016). The temperature and relative humidity during the 48-h storage period ranged from $24.5{ }^{\circ} \mathrm{C}$ to $26.4{ }^{\circ} \mathrm{C}$ and $63.7 \%$ to $73.9 \%$, respectively.

Conidial viability was determined by calculating the germination percentage, using a method similar to that described by Jadhav \& Patil (2016), via direct counting in the Petri dishes $24 \mathrm{~h}$ after plating, with an optical microscope at 400x magnification. The conidia that exhibited a germ tube whose length was greater than or equal to its diameter were considered germinated, with 100 conidia counted per dish, based on the methodology adapted from Silva \& Neves (2016).

Temperature and relative humidity were monitored using a portable digital thermohygrometer.
Readings were taken during the storage to monitor variations throughout the study.

Data were submitted to homogeneity of variance and normality analyses using the Levene and Kolmogorov-Smirnov tests, respectively. Next, an analysis of variance was performed with the F-test $(\mathrm{p}<0.05)$ and conidial germination means compared by the Tukey test $(\mathrm{p}<0.05)$ using the R software $(\mathrm{R}$ Core Team 2018).

\section{RESULTS AND DISCUSSION}

The conidial germination was influenced by the spray solution composition as a function of the storage time and used adjuvant. When no adjuvant was used, germination means differed significantly ( $p<0.05 ; \mathrm{msd}=3.42 \%$ by the t-test $)$ from the solutions with adjuvants, regardless of the storage time. The largest discrepancy was observed between the pure solution (no adjuvant) and $B$. bassiana + Orobor, when stored for $48 \mathrm{~h}$, with a 9.2-fold decline in germination in these treatments. This negative effect was accentuated from $24 \mathrm{~h}$ of storage onwards (Figure 1).

Including adjuvants in the spray solution may increase the control efficacy; however, knowledge regarding the interaction between adjuvants and entomopathogenic fungi is still incipient, and research on the topic is vital to aid in the decision making in the field and increase the application efficiency and treatment efficacy without losing the germination characteristics of the fungal spores.

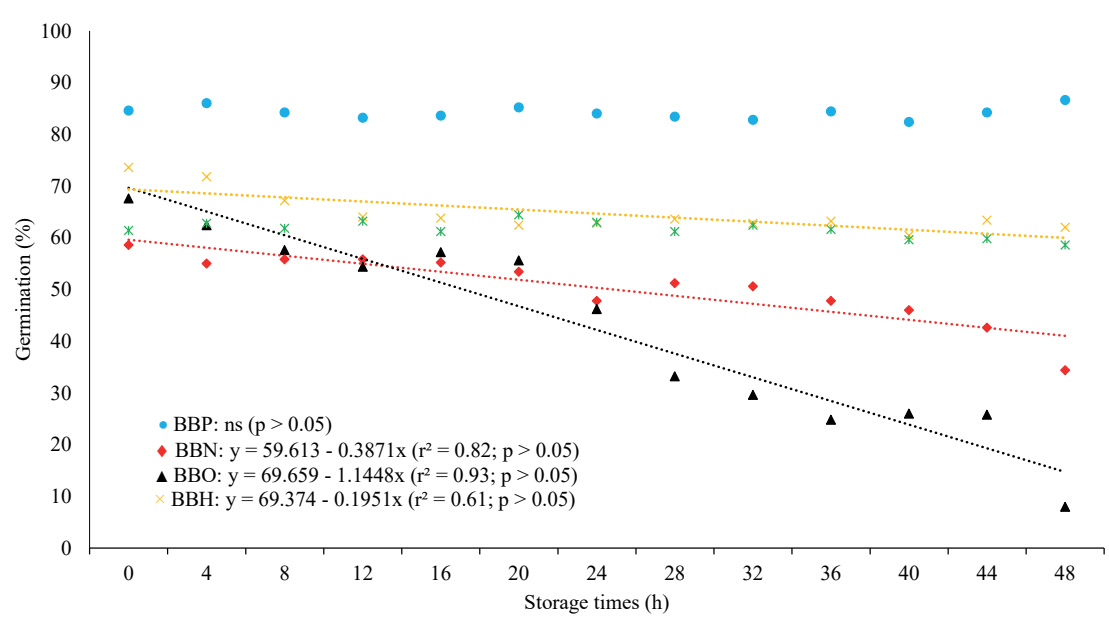

Figure 1. Germination of Beauveria bassiana conidia in stored spray solution with and without adjuvants. BBP: pure B. bassiana; BBN: B. bassiana + Nimbus; BBO: B. bassiana + Orobor; BBH: B. bassiana + Helper Neutrum; BBT: B. bassiana + TA-35; ns: not significant responses at $5 \%$ of probability. 
Adjuvants are essential in facilitating the bioinsecticide contact with the target insect. Mota et al. (2017) reported that using adjuvants in spray solutions reduced the survival in adult $H$. hampei. Lopes et al. (2011) found that conidia may remain dry within small oil bubbles in oil-in-water emulsions, remaining protected from heat, chemical pesticides and environmental damage.

Although the mean conidial germination was higher in the pure solution (no adjuvants) than in the spray mixtures, adjuvants may be a viable alternative, in terms of improving the application efficiency, by ensuring a better spreading, impaction, adhesion, retention and spray droplet wetting to increase the contact between the target insect and the bioinsecticide (Santos et al. 2012). However, in terms of control efficacy, a decreased germination may be caused by acids entering the conidial plasma membrane (Mishra et al. 2013).

The results obtained by Lizzy et al. (2015) using different concentrations of Tween 80 showed an increase in germination for $0.1 \% \mathrm{~B}$. bassiana. The results of the present study differed, since manufacturer-recommended concentrations of the adjuvants TA-35 and Helper Neutrum lowered the germination of $B$. bassiana conidia by approximately $24 \%$, when compared to the pure solution. This is likely due to the compounds present in the composition of these adjuvants. While there is no information on the package insert of Helper, regarding its composition, the sodium laurel ethyl sulfate in TA35, also used by Turro et al. (2008) to control coffee berry borer, may have inhibited the conidial growth as a function of the electrolyte balance of the spray solution (Queiroz et al. 2008), since conidia were more sensitive to the compound in all the storage periods.

The results of $B$. bassiana conidia germination in the solution added with the mineral oil-based adjuvant Nimbus, when compared with the pure solution, differed from those obtained by Silva et al. (2009). These authors used the B. bassiana isolate CG 432 with Nimbus and found no difference in the conidial germination, if compared to the control treatment (pure B. bassiana without adjuvants). This indicates an association with the IBCB 66 isolate used here, likely susceptible to the adjuvant composition, which may have altered its virulence and therefore its effectiveness in the field.

The spray mixture with Orobor N1 exhibited a lower germination across all the storage times, particularly in relation to the pure solution and that added with Helper. This result may be explained by the action of the orange bagasse extract. Orobor N1 may dissolve cell walls, which could act on conidia during their storage and prevent their germination. Potrich et al. (2011) also reported a decline in conidial germination, with $79 \%$ germination for a manufacturer-recommended dose of Tween 80 .

The adjuvants tested in the present study reduced the viability of $B$. bassiana conidia; however, Mishra et al. (2013) found that adjuvants had little effect on the germination of entomopathogenic fungi. As such, if a prepared spray solution must be applied, farmers may still use the solution, provided none of the adjuvants tested here are added. It is important to underscore that conidial germination does not guarantee the pathogenicity of $B$. bassiana, since germinated conidia cannot form colonies.

Conidial germination changed over time as a function of the exposure to Nimbus, which may affect the fungal virulence against the target insect. This corroborates the findings of Silva et al. (2009), who reported that the interaction between entomopathogenic fungi and adjuvants may reduce the vegetative growth, viability and sporulation, and even modify the genetic composition of the fungi, affecting their virulence and efficiency in the field.

The spray solution added with Orobor decreased the conidial germination, likely due to the presence of limonene, nitrogen and boron in its composition. A decline in the $B$. bassiana conidia germination using different adjuvants was also observed by Potrich et al. (2011). Research on this adjuvant in conjunction with B. bassiana is scarce, underscoring the importance of investigating the interaction between the fungus and individual compounds present in the product, since its use as an alternative for a better spreading and coverage may lower the quality of the spray solution for insect control.

Under field conditions, the adjuvants Nimbus, Orobor and Helper may negatively affect the conidial germination and are therefore not a viable alternative for use with the spray solutions studied here, since a lower conidial germination could compromise the virulence of the entomopathogen in the field, in contrast with the findings of Lizzy et al. (2015). Based on our study conditions, the best alternative for farmers would be to use the commercial insecticide without including adjuvants in the spray solution, despite the fact that the mixture containing Helper 
did not differ from the pure solution at a storage time of $4 \mathrm{~h}$.

The results of conidial germination in water without adjuvants were considered satisfactory, given the high temperatures during the storage periods. In the laboratory, $84 \%$ of germination was obtained without adjuvants. The addition of Helper as adjuvant allowed the conidial germination to remain above $70 \%$ for only $4 \mathrm{~h}$, after which the conidial viability declined significantly.

\section{CONCLUSIONS}

1. A biological spray solution containing Beauveria bassiana conidia with no adjuvants remains viable for use up to $48 \mathrm{~h}$ after the preparation;

2. The adjuvants Helper Neutrum, TA-35, Nimbus and Orobor reduce the conidial germination of $B$. bassiana after the solution storage.

\section{ACKNOWLEDGMENTS}

The authors thank the Coordenação de Aperfeiçoamento de Pessoal de Nível Superior (Capes), Conselho Nacional de Desenvolvimento Científico e Tecnológico (CNPq), Fundação de Amparo à Pesquisa do Estado de Minas Gerais (Fapemig) and Simbiose Agro, for supporting this study.

\section{REFERENCES}

CHECHETTO, R. G.; GANDOLFO, M. A.; VOLTAN, D. S. Avaliação da retenção de calda de pulverização na cultura do milho com diferentes adjuvantes. Revista Científica Eletrônica de Agronomia, v. 21, n. 1, p. 30-37, 2012.

COMPANHIA NACIONAL DE ABASTECIMENTO (Conab). Acompanhamento da safra brasileira (café): $4^{\circ}$ levantamento. 2017. Disponível em: http://www.conab. gov.br. Acesso em: 25 abr. 2018.

CORADINI, C.; PICCININI, F.; REIMCHE, G. B.; COSTA, I. F. D.; MACHADO, S. L. O. Efeito de óleo essencial de laranja associado a fungicidas no controle de doenças foliares do trigo. Summa Phytopathologica, v. 42, n. 1, p. 105-106, 2016.

COSTA, M. A.; LOUREIRO, E. S.; PESSOA, L. G. A.; DIAS, P. M. Compatibilidade de inseticidas utilizados na cultura do eucalipto com Metarhizium rileyi (Farlow) (Nomuraea rileyi). Revista de Agricultura Neotropical, v. 5, n. 3, p. 44-48, 2018.
GREEN, J. M.; BEESTMAN, G. B. Recently patented and commercialized formulation and adjuvant technology. Crop Protection, v. 26, n. 3, p. 320-327, 2007.

INTERNATIONAL COFFEE ORGANIZATION (ICO). Total production by all exporting countries. 2017. Disponível em: http://www.ico.org/. Acesso em: 10 jul. 2018.

JADHAV, R. S.; PATIL, S. D. Effect of various adjuvants on growth and development of the entomopathogenic fungi Beauveria bassiana (Balsamo) Vuillemin. International Journal of Plant Protection, v. 9, n. 2, p. 401-408, 2016.

JENKINS, N. E.; GRZYWACZ, D. Quality control of fungal and viral biocontrol agents: assurance of product performance. Biocontrol Science and Technology, v. 10, n. 6, p. 753-777, 2000.

LIZZY A.; LAING, M. D.; MILLER, R. M. Effect of surfactants and temperature on germination and vegetative growth of Beauveria bassiana. Brazilian Journal of Microbiology, v. 46, n. 1, p. 67-74, 2015.

LOPES, R. B.; PAULI, G.; MASCARIN, G. M.; FARIA, M. Protection of entomopathogenic conidia against chemical fungicides afforded by an oil-based formulation. Biocontrol Science Technology, v. 21, n. 2, p. 125-137, 2011.

LORENCETTI, G. A. T.; POTRICH, M.; MAZARO, S. M.; LOZANO, E. R.; GONÇALVES, T. E.; DALLACORT, S. Ocorrência espontânea de Beauveria bassiana (Bals. Criv.) Vuill. 1912 (ASCOMYCETES: CLAVICIPITACEAE) sobre Thaumastocoris peregrinus (HEMIPTERA: THAUMASTOCORIDAE). Ciência Florestal, v. 27, n. 4, p. 1403-1407, 2017.

MADUREIRA, R. P.; RAETANO, C. G.; CAVALIERI, J. D. Interação pontas-adjuvantes na estimativa do risco potencial de deriva de pulverizações. Revista Brasileira de Engenharia Agrícola e Ambiental, v. 19, n. 2, p. 180185, 2015.

MARQUES, E. J.; ALVES, S. B.; MARQUES, I. M. R. Virulência de Beauveria bassiana (Bals.) Vuill. a Diatraea saccharalis (F.) (Lepidoptera: Crambidae) após armazenamento de conídios em baixa temperatura. Anais da Sociedade Entomológica do Brasil, v. 29, n. 2, p. 303307, 2000.

MERTZ, N. R.; ALVES, L. A.; MARCOMINI, A.; OLIVEIRA, D. P.; SANTOS, J. Efeito de produtos fitossanitários naturais sobre Beauveria bassiana (Bals.) Vuill. in vitro. BioAssay, v. 5, n. 3, p. 1-10, 2010.

MISHRA, S.; KUMAR, P.; MALIK, A. Evaluation of Beauveria bassiana spore compatibility with surfactants. International Scholarly and Scientific Research \& Innovation, v. 1, n. 7, p. 8-12, 2013. 
MOTA, L. H. C.; SILVA, W. D.; SERMARINI, R. A.; DEMÉTRIO, C. G. B.; BENTO, J. M. S.; DELALIBERA JUNIOR, I. Autoinoculation trap for management of Hypothenemus hampei (Ferrari) with Beauveria bassiana (Bals.) in coffee crops. Biological Control, v. 111, n. 1, p. 32-39, 2017.

MWAMBURI, L. A.; LAING, M. D.; MILLER, R. M. Effect of surfactants and temperature on germination and vegetative growth of Beauveria bassiana. Brazilian Journal of Microbiology, v. 46, n. 1, p. 67-74, 2015.

NEVES, P. M. O. J.; HIROSE, E. Seleção de isolados de Beauveria bassiana para o controle biológico da brocado-café, Hypothenemus hampei (Ferrari) (Coleoptera: Scolytidae). Neotropical Entomology, v. 1, n. 34, p. 7782, 2005.

OLIVEIRA, C. M.; AUAD, A. M.; MENDES, S. M.; FRIZZAS, M. R. Economic impact of exotic insect pests in Brazilian agriculture. Journal of Applied Entomology, v. 137, n. 1, p. 1-15, 2012.

POTRICH, M.; NEVES, P. M. O. J.; ALVES, L. F. A.; PIZZATTO, M.; SILVA, E. R. L.; LUCKMANN, D.; GOUVEA, A.; ROMAN, J. C. Virulência de fungos entomopatogênicos a ninfas de Bemisia tabaci (Genn.) (Hemiptera: Aleyrodidae). Semina: Ciências Agrárias, v. 32, supl. 1, p. 1783-1792, 2011.

QUEIROZ, A. A.; MARTINS, J. A. S.; CUNHA, J. P. A. R. Adjuvantes e qualidade da água na aplicação de agrotóxicos. Bioscience Journal, v. 24, n. 4, p. 8-19, 2008.
R CORE TEAM. $R$ : a language and environment for statistical computing. Vienna: R Foundation for Statistical Computing, 2017.

SANTOS, P. S.; SILVA, M. A. Q.; MONTEIRO, A. C.; GAVA, C. A. T. Selection of surfactant compounds to enhance the dispersion of Beauveria bassiana. Biocontrol Science and Technology, v. 22, n. 3, p. 281-292, 2012.

SILVA, A. S.; QUINTAL, A. P. N.; MONTEIRO, S. G.; DOYLE, R. L.; SANTURIO, J. M.; BITTENCOURT, V. R. E. P. Ação do fungo Beauveria bassiana, isolado 986, sobre o ciclo biológico do cascudinho Alphitobius diaperinus em laboratório. Ciência Rural, v. 36, n. 6, p. 1944-1947, 2006.

SILVA, R. Z.; NEVES, P. M. O. J. Estabilidade de conídios de Beauveria bassiana (Bals.) Vuill. acondicionados em diferentes embalagens. Arquivos do Instituto Biológico, v. 83, n. 1, p. 1-7, 2016.

SILVA, R.; NEVES, P.; SANTORO, P.; CAVAGUCHI, S. Efeito de agroquímicos à base de óleo mineral e vegetal sobre a viabilidade dos fungos entomopatogênicos Beauveria bassiana (Bals.) Vuillemin, Metarhizium anisopliae (Metsch.) Sorokin e Paecilomyces sp. Bainier. Bioassay, v. 1, n. 1, p. 1-5, 2009.

TURRO, A. F.; RICARDO, F. S.; PETEIRA, B.; CAMPOS, A. C.; COS, J. I. D. Efecto de la intensidad luminosa y la aplicación de Beauvearia bassiana sobre las poblaciónes de Hypothenemos hampei (FERR) (Coleoptera: Scolytidae). Revista de Protección Vegetal, v. 23 , n. 8, p. 160-167, 2008. 